\title{
XI. Specimen of a new nomenclature for meteorological science
}

\section{Thomas Forster Esq.}

To cite this article: Thomas Forster Esq. (1816) XI. Specimen of a new nomenclature for meteorological science, Philosophical Magazine Series 1, 47:213, 45-47, DOI:

$10.1080 / 14786441608638793$

To link to this article: http://dx.doi.org/10.1080/14786441608638793

册 Published online: 27 Jul 2009.

Submit your article to this journal $\sqsubset \pi$

Џ Article views: 2

Q View related articles $₫$ 
Mr. Sheffield discovered molybdina in the same neighbourhood; and I found a very well defined specimen of wolfram on guartz in the bed of the river Calduo.

The coall-formation of Whiteliaven is covered at St. Bees Head by a curious bituminous clay, formed, as it were, of a number of hollow cones inserted into each other, till a column is formed whose length (about a foot) is equal to the thickness of the stratum, and by the lateral aggregation of these columns the whole bed is formed: over this is a limestone containing magnesia and iron, and exactly resembling some of the dark-coloured more compact beds at Whitby. Above this is a red sandstone, connected with which is clay, marl, and gypsum. Thus a beantiful uniformity exists on the two sides of the island; for if we suppose the limestone, \&c. of the neighbourhood of Cockermouth to accord with the netalliferous rocks of Alston Moor, the Whitehaven coal-formation with that of Newcastle, the mannesian limestone of St. Bees with the Sunderland limestone, and the red sandstone with that of the Tees, - we have the series complete. Notwithstanding the opinion of Professor Kidd, that our rocks are in a state of absolute confusion, I think I could show that our rocks, though numerons and occurring in small compass, are remarkably regular in their relations: but it would be leading me too far from the olject of this paper, which is merely intended as a notice of some rocks which have lately fallen under my observation.

XI. Specimen of a new Nomenclature for Meteorological Scionce. By Thomas Forster, Esq.

\section{To Mr. Tilloch.}

SrR, - T HE propensity which the English writers have to borrow from other languages terms used technically in the sciences, renders their works so very difficult to be understood by those who do not understand the languages from which the words are derived. Besides which, their habit of borrowing words has a tendency to obliterate the distinctive characters of different tongues, and has already marle the English a motiey and ruphilosophical group of exotic words, which one might well suppose had sprung from the confusion of Babel. It is my intention to construct a scientific nomenclature (entirely out of our own language, or its mother-tongue the Saxon), and to adopt it in my journals of meteorology. I subjoin at present only a few technical names, which I shall henceforward use, and which I have already made, partly from the consideration above alluded to, and partly from having been repcatedly desirea by artists 
and others who have made use of Mr. Howard's paper on the Clouds, and of my last Essay on Atmospheric Phænomena, in order to depict more accurately clouds, \&c. and to make an English nomenclature, as many persons unaccustomed to Latin could not retain the distinctions of the Latin nomenclatures in their memories. The Latin terms for clouds, originally made by L. Howard, are very useful in descriptions in Latin, and in those which are to go abroad, or which are for scientific persons only; and should, I think, he inserted with the others. But we ought to use terms of science constructed out of the language in which that seience is treated of.-I subjoin the following names for clouds, substituted for the former ones, and others substituted for those which I constructed from the Latin for halos and other phænomena made by refraction; and shall proceed in future to a more extended nomenclature for other terms of meteorological science.

Cirrus, or Curlcloud. I propose to call this the curlcloud, from its constant tendency to assume the fibrous and flexible forms. It is bent and curled in all directions; and curlcloud comes nearest to its old name cirrus, of which cirrulus and curl are diminutives.

Crrrocumulus, or Sondercroud, i.e. cloud consisting of an aggregate of clouds asunder (from A. S. sond, Old Eng. asonder and sonder): the distinguishing marks of this cloud being that of separate orbs aggregated together, and the change to this cloud from others is a separation of continuity into particules.

Cirrostratus, or Wanecloud. The constantly evanescent state of this cloud in all its forms suggests this name. It is always subsiding or altering its form, or waning, a verb now not so much used as formerly, and which comes from the AngloSaxon Fynizean, evanescere; whence also our words to faint, feint, \&c.

Cumulus, or Stackencroud, i.e. stackt cloud, from being piled or heaped up; to stack being a known verb for piling up. The participial termination $e n$ gives the word a pleasanter sound then stackcloud.

Stratus, or Fallcloud, being the subsidence or falling of the aqueous particles in the evening, I first thought of evencloud, corresponding to the German alendwolke; but that is not definite enough, as many clouds become evening clouds.

Cumulostratus, or Twaincloud; being the visible result often of the coalescence of two modifications (supposed with opposite electricities) and when it forms primarily a similar union being conjectured of particules separately electrified as soon as formed. 
Nimbes, or Raincloud, may be subdivided, and described shortly, as stormcloud, thundercloud, \&c.

Hatos will be called Moonrings, Sunrings, \&c.

Coronas will be called Mooncrowns, \&c. But I give this merely as an imperfect specimen of the nomenclature $I$ am making, and which I shall publish and give in your Magazine in a short time: meanwhile I shall adopt these words of Saxon derivation in my journal, and give an explanation in the notes to those not inserted here.

I am, \&c.

Thomas Forster.

XII. On the Influence of the Atmosphere on the Electro-Galvanic Column of M. De Luc. By Mr. J. Tatum.

\section{To Mr. Tilloch.}

Sir, - Although various accounts of Mr. De Lue's electrical column have appeared in your Magazine, I do not recollect that nny journal of its action as connected with atmospherical influence has yet appeared. Having long observed the very considerable alteration which every thermometrical change in the atmosphere produced on the operation of this instrument, I determined on keeping a regular journal, and noticing its corresponding change with those indicated by the barometer, thermometer, De Luc's hygrometer, and the direction of the wind. The results of my observations as deduced from my daily register of those instruments have convinced me that the greatest changes in the oscillations of the ball on De Luc's columns are chieffy, if not entirely owing to the increased temperature of the atmosphere, and not to its moisture, as some of my philosophical friends had supposed. By the following extract of my journal, it appears that when the thermometer was $52^{\circ}$ and hygrometer $81^{\circ}$, the ball of the columns oscillated only 248 times in a minute; but when the thermometer was $56^{\circ}$ and the hygrometer $50^{\circ}$, it oscillated 284 times; a satisfactory proof that the heat and not the moisture of the atmosphere increased the action of the instrument. In the latter case, I had removed the instrument to the gallery of my lecture-room, where the thermometer was $14^{\circ}$ higher, and the hygrometer $5^{\circ}$ drier than at the place from whence it was removed.

It is proper also to add, that from the 1 st till the 13 th of the month the thermometer and hygrometer were no: in the same apartment with the electrical columns, a circuinstance which may have occasioned some difference in the results. Since that 